\title{
Acoustic impedance and basal shear stress beneath four Antarctic ice streams
}

\author{
David G. VAUGHAN, Andrew M. SMITH, P. Ghandrika NATH, Emmanuel LE MEUR \\ British Antarctic Survey, Natural Environment Research Council, Madingley Road, Cambridge CB3 0ET, England \\ E-mail:d.vaughan@bas.ac.uk
}

\begin{abstract}
The acoustic impedance of the subglacial material beneath $7.2 \mathrm{~km}$ profiles on four ice streams in Antarctica has been measured using a seismic technique. The ice streams span a wide range of dynamic conditions with flow rates of $35-464 \mathrm{~m} \mathrm{a}^{-1}$. The acoustic impedance indicates that poorly lithified or dilated sedimentary material is ubiquitous beneath these ice streams. Mean acoustic impedance across each profile correlates well with basal shear stress and the slipperiness of the bed, indicating that acoustic impedance is a good diagnostic not only for the porosity of the subglacial material, but also for its dynamic state (deforming or non-deforming). Beneath two of the ice streams, lodged (non-deforming) and dilated (deforming) sediment coexist but their distribution is not obviously controlled by basal topography or ice thickness. Their distribution may be controlled by complex material properties or the deformation history. Beneath Rutford Ice Stream, lodged and dilated sediment coexist and are distributed in broad bands several kilometres wide, while on Talutis Inlet there is considerable variability over much shorter distances; this may reflect differences in the mechanism of drainage beneath the ice streams. The material beneath the slow-moving Carlson Inlet is probably lodged but unlithified sediment; this is consistent with the hypothesis that Carlson Inlet was once a fast-flowing ice stream but is now in a stagnant phase, which could possibly be revived by raised basal water content. The entire bed beneath fast-flowing Evans Ice Stream is dilated sediment.
\end{abstract}

\section{INTRODUGTION}

The processes that allow ice to stream are the most important processes in controlling the overall configuration of ice sheets. If streaming were absent, the surface elevation of much of both the East and West Antarctic ice sheets would be many hundreds of metres higher than it is today (Vaughan and Bamber, 1998), and the Laurentide ice sheet would probably have been considerably thicker (Boulton and Jones, 1979). Furthermore, the apparent rapidity with which these processes can change (Retzlaff and Bentley, 1993; Clarke and others, 2000) suggests that they will be important to the future evolution of the West Antarctic ice sheet.

Ice streams generate only moderate, or even low, driving stresses but achieve high flow velocities. This relationship implies that the restraining force generated by basal and marginal drag is also low. While we should not overlook the processes that reduce drag through shear margins, there is considerable evidence that for streaming to develop, basal lubrication must be present. Two processes provide such lubrication: sliding of the ice over its bed, resulting from the presence of free water between the ice and rock beneath (Rose, 1979; Cuffey and others, 1999), or deformation in a layer of soft sediment beneath the ice (Alley and others, 1986). These processes are, however, poorly understood and appear in ice-sheet models as gross, heuristic parameterizations. A recent review of the numerical modelling of ice sheets (Hulbe and Payne, 2001) identified that "the glaring omission of subglacial processes from large-scale ice sheet models must be addressed before modellers can start to address the wealth of data becoming available".
In this paper, we describe new investigations of four Antarctic ice streams using seismic techniques. The ice streams (Rutford Ice Stream, Carlson Inlet, Talutis Inlet and

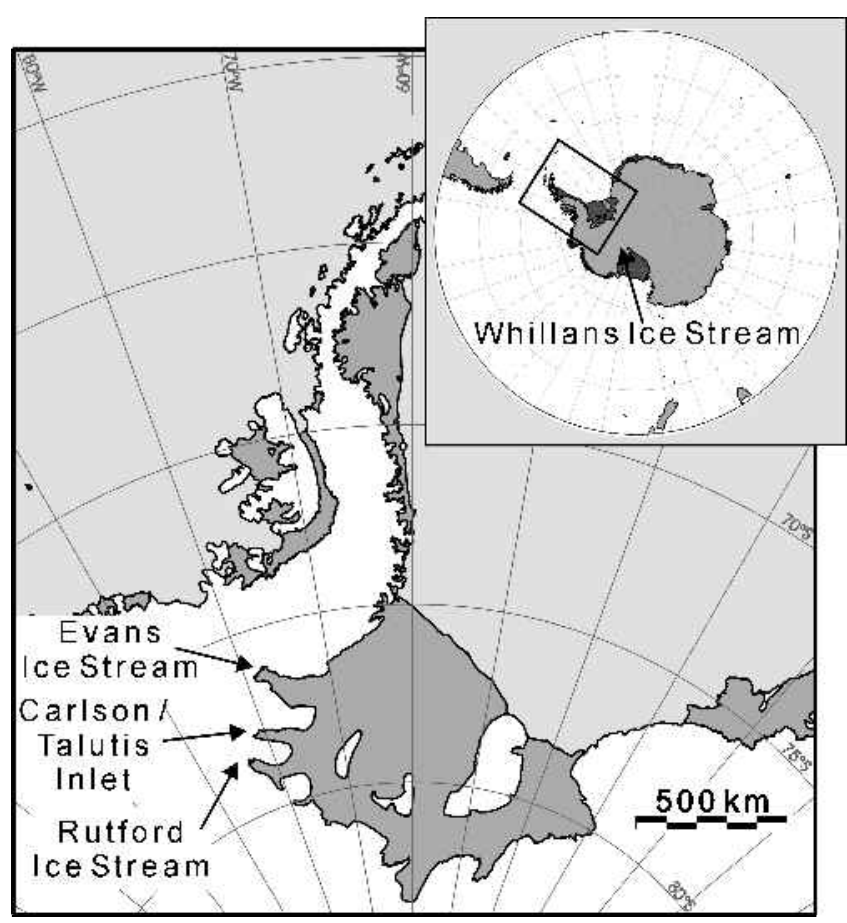

Fig. 1. Location map of Antarctica showing the ice streams on which data were collected. 

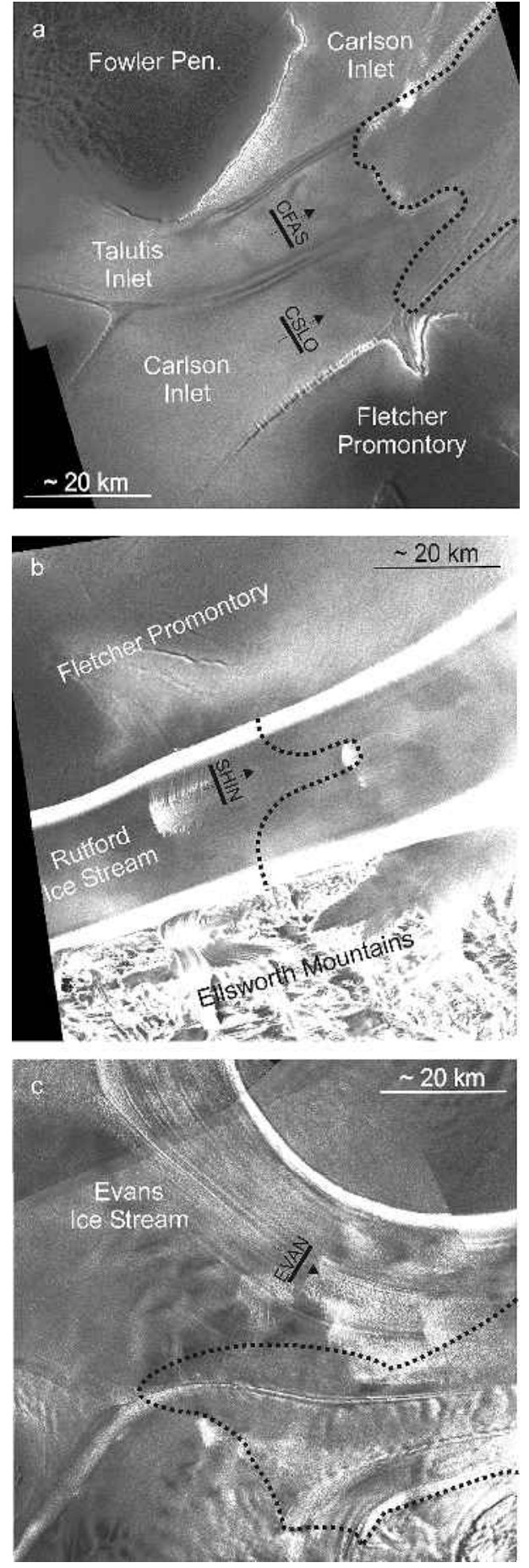

Fig. 2. ERS-1 SAR subscenes of locations for new seismic profiles. (a) CFAS and CSLO lines on Talutis Inlet and Carlson Inlet. (b) SHIN line on Rutford Ice Stream. (c) EVAN line on Evans Ice Stream. In each frame, the arrow indicates the direction of ice flow, and the approximate grounding line determined from SAR interferometry is shown by the dotted line. The highly fractured shear margins bounding Rutford and Evans Ice Streams appear light in the SAR imagery due to increased backscatter from the fractures. (Grounding line for Evans Ice Stream is shown courtesy of E. Rignot ( NASA/Fet Propulsion Laboratory, Pasadena, CA).)

Evans Ice Stream) feed Ronne Ice Shelf (Fig. 1), and are all clearly delineated in European Remote-sensing Satellite-1 (ERS-1) synthetic aperture radar (SAR) images (Fig. 2), but they exhibit a wide range of flow conditions, from non-streaming $\left(\sim 35 \mathrm{~m} \mathrm{a}^{-1}\right)$ to fully streaming $\left(\sim 460 \mathrm{~m} \mathrm{a}^{-1}\right)$. Despite their names, each of these ice streams can be considered to have characteristics of both outlet glaciers and ice streams. Although only the southwestern boundary of Rutford Ice Stream has exposed rock outcrops, all four flow in deep troughs (Doake and others, 1983) and so may in some ways be considered outlet glaciers. However, they also have clear linear shear margins and so may also be considered to be similar to ice streams. For convenience, we use the term ice streams, exclusively, to refer to these glaciers.

\section{LOGATION OF SITES AND GHARAGTER OF THE ICE STREAMS}

Between December 1999 and February 2000, we collected data along four $7.2 \mathrm{~km}$ profiles in Antarctica during the Millennium Seismic Safari (Vaughan and others, 2000). These were the "CSLO line", $15 \mathrm{~km}$ upstream of the grounding line on Carlson Inlet, the "CFAS line", $16 \mathrm{~km}$ upstream of the grounding line on Talutis Inlet, the "SHIN line", 6-10 km upstream of the grounding line on Rutford Ice Stream, and the "EVAN line", 12-22 km upstream of the current best estimate of the grounding line on Evans Ice Stream.

\subsection{Carlson Inlet (CSLO line)}

In satellite images, Carlson Inlet (Fig. 2a) appears to have many characteristics typical of an ice stream; however, Frolich and others (1989) measured Carlson Inlet as flowing at around $7 \mathrm{~m} \mathrm{a}^{-1}$ in its upstream parts, and that measurement was extrapolated using SAR interferometry to show that, whatever its history, Carlson Inlet is not currently streaming. Indeed it flows at less than one-tenth of the speed of its neighbour Rutford Ice Stream (Frolich and Doake, 1998). Frolich and others (1989) also calculated that Carlson Inlet is frozen to its bed, although this has since been disputed by Smith (2000).

Carlson Inlet occupies a deep linear trough in the bed (Doake and others, 1983), and it does have smooth linear margins that may well be relict of a period of more rapid flow (Fig. 2a). Since it appears so similar to Rutford Ice Stream, it is tempting to hypothesize that Carlson Inlet is a formerly active ice stream (Frolich and others, 1989) which has perhaps only recently switched off, in a similar manner to Ice Stream C, Antarctica (Retzlaff and Bentley, 1993). There is, however, no direct evidence for this. Indeed, ground-penetrating radar (GPR) data collected in the margin between Carlson Inlet and Fletcher Promontory in 1995 showed no evidence of buried crevassing, which could have indicated when Carlson Inlet was active; only that it has probably been inactive for more than $\sim 300$ years.

\subsection{Talutis Inlet (GFAS line)}

Talutis Inlet is an ice stream that flows at intermediate speed through the slow-moving ice of Carlson Inlet (Fig. 2a). Little was known about this ice stream prior to the present investigations, but it was suspected to be intermediate between, fully stagnant and fully streaming conditions.

\subsection{Rutford Ice Stream (SHIN line)}

Rutford Ice Stream (Fig. 2b) is a "typical Antarctic outlet glacier" (Doake and others, 2001). It flows at up to $400 \mathrm{~m} \mathrm{a}^{-1}$ in a deep trough in the bed (Doake and others, 1983). The determinations of acoustic impedance described below supplement earlier data collected on the Tyree, Young and New 

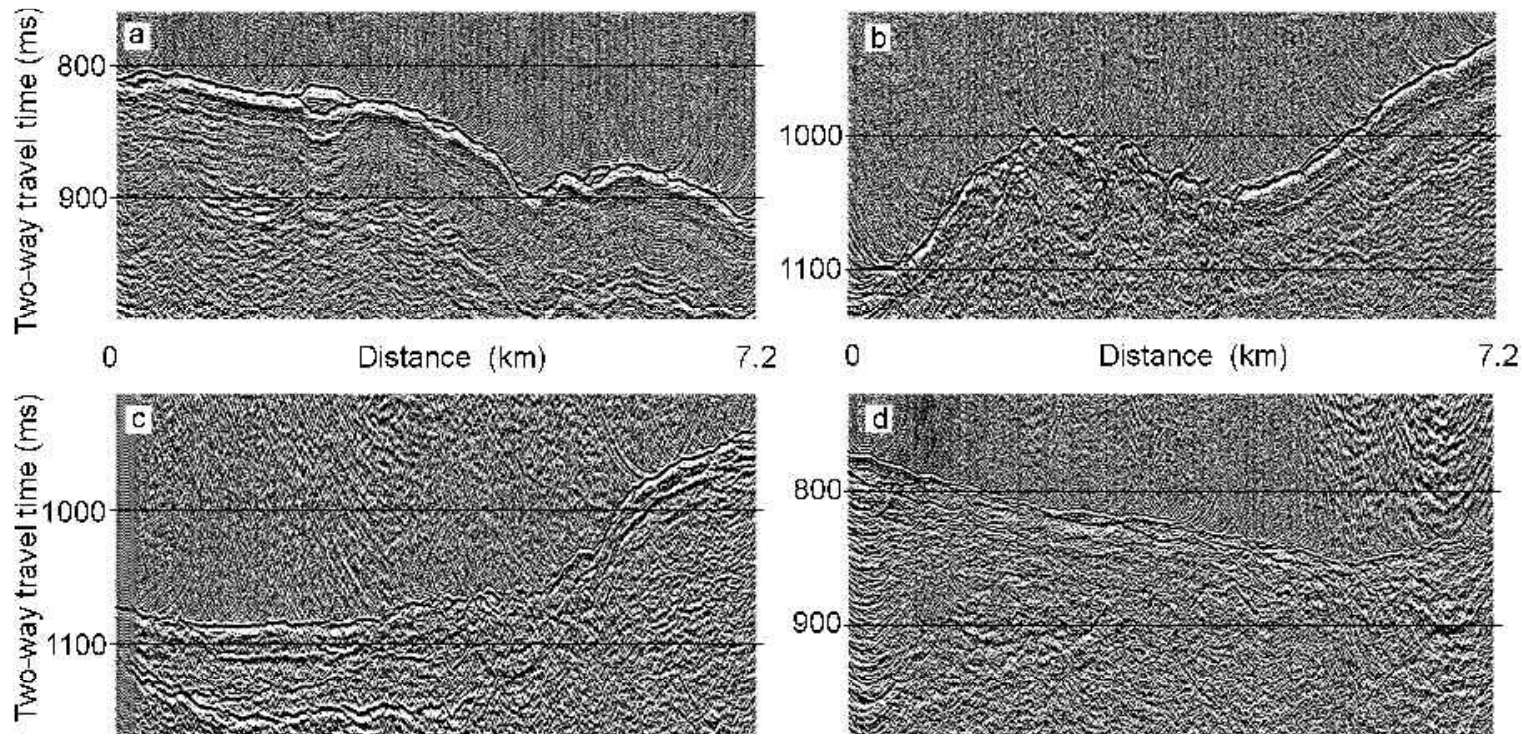

Fig. 3. Reflection seismic sections. (a) CSLO line; (b) CFAS line; (c) SHIN line; (d) EVAN line. Ice flow is into the page.

lines, respectively $\sim 45, \sim 60$ and $\sim 95 \mathrm{~km}$ upstream of the grounding line (Smith, 1997a, b).

\subsection{Evans Ice Stream}

Evans Ice Stream (Fig. 2c) is a wide and rapidly flowing ice stream with several distinct tributaries which coalesce 50$100 \mathrm{~km}$ above the grounding line (Bamber and others, 2000). The grounding line itself has proved difficult to map, even using satellite interferometric SAR data to detect tidal flexing (personal communication from E.J. Rignot, 2001) - a method that has been successful elsewhere (Goldstein and others, 1993; Schmeltz and others, 2001). It is thus probable that the grounding line of Evans Ice Stream is complex and sinuous, a result of the subdued subglacial topography in this area.

\section{SEISMIG TEGHNIQUES}

The seismic techniques employed in this study allow measurement of the acoustic impedance of the material directly beneath the ice, and this property allows discrimination of its mechanical state. Earlier papers have described the techniques in detail, as applied to both Antarctic ice streams (Smith, 1997a,b) and glaciers in Svalbard (Smith and others, 2002). Our techniques were not significantly different to those described in those papers and so are only summarized below.

At three sites along each profile we used a long-record shot, with sufficient source energy and recording time to acquire the primary echo and first multiple echo from the bed. The source for these long-record shots was a $2 \mathrm{~kg}$ cast primer (Pentolite) placed in a $20 \mathrm{~m}$ deep hole which was then filled with snow. The echoes were recorded on 24 vertically oriented geophones with a natural frequency of $40 \mathrm{~Hz}$. The geophones were buried with a horizontal spacing of $10 \mathrm{~m}$ and a maximum offset of $270 \mathrm{~m}$. For each trace from the long-record shots, we measured the ratio of energy in the primary and first multiple echoes, and from this calculated the basal reflection coefficient. Using this method to calculate the reflection coefficient means that the degree of energy coupling between shot and the firn, and attenuation in the bulk of the ice column, need not be known, as these values cancel in the calculation (Smith, 1997a). From the reflection coefficient and an assumed acoustic impedance of the basal ice $\left(3.33 \times 10^{6} \mathrm{~kg} \mathrm{~m}^{-2} \mathrm{~s}^{-1}\right)$ (Atre and Bentley, 1993; Smith, 1997a) we then calculated the acoustic impedance of the subglacial material.

The measurements of acoustic impedance obtained from the long-record shots were then extrapolated along the entire $7.2 \mathrm{~km}$ line by reference to the energy of the primary bed reflection determined along migrated single-fold seismic reflection profiles (Fig. 3). For these reflection profiles, we needed to image only the primary bed reflection, and so used smaller charges ( $300 \mathrm{~g}$ cast primers) in $20 \mathrm{~m}$ deep snow-filled holes. These profiles also yielded the ice thickness.

In the calculation of acoustic impedance, we took account of the low-velocity surface ice (determined in a separate walkaway survey), spherical spreading and acoustic attenuation of the ice (assumed to be $0.21 \times 10^{-3} \mathrm{~m}^{-1}$ ) (Smith, 1997a). The estimate of the uncertainty in acoustic impedance was derived from the variability in the traces recorded from each shot. Only the mean of acoustic impedances for each shot is shown in Figure 4, and so each should be considered as the mean value over the portion of the bed sampled by a single shot $(\sim 125 \mathrm{~m})$.

\section{ANCILLARY MEASUREMENTS}

During the seismic surveys, ancillary measurements were also made to help characterize the ice flow and to calculate the driving stress and basal shear stress for each glacier. The results are presented in Table 1.

\subsection{Velocity}

A global positioning system (GPS) receiver was used to collect static data (Ll-only) continuously for several days at a stake at the centre of each seismic profile. The data were broken into $\sim 1$ day segments, and then processed without reference to a static receiver, but using precise ephemeris and GPSurvey software. Linear regression of the 1 day posi- 

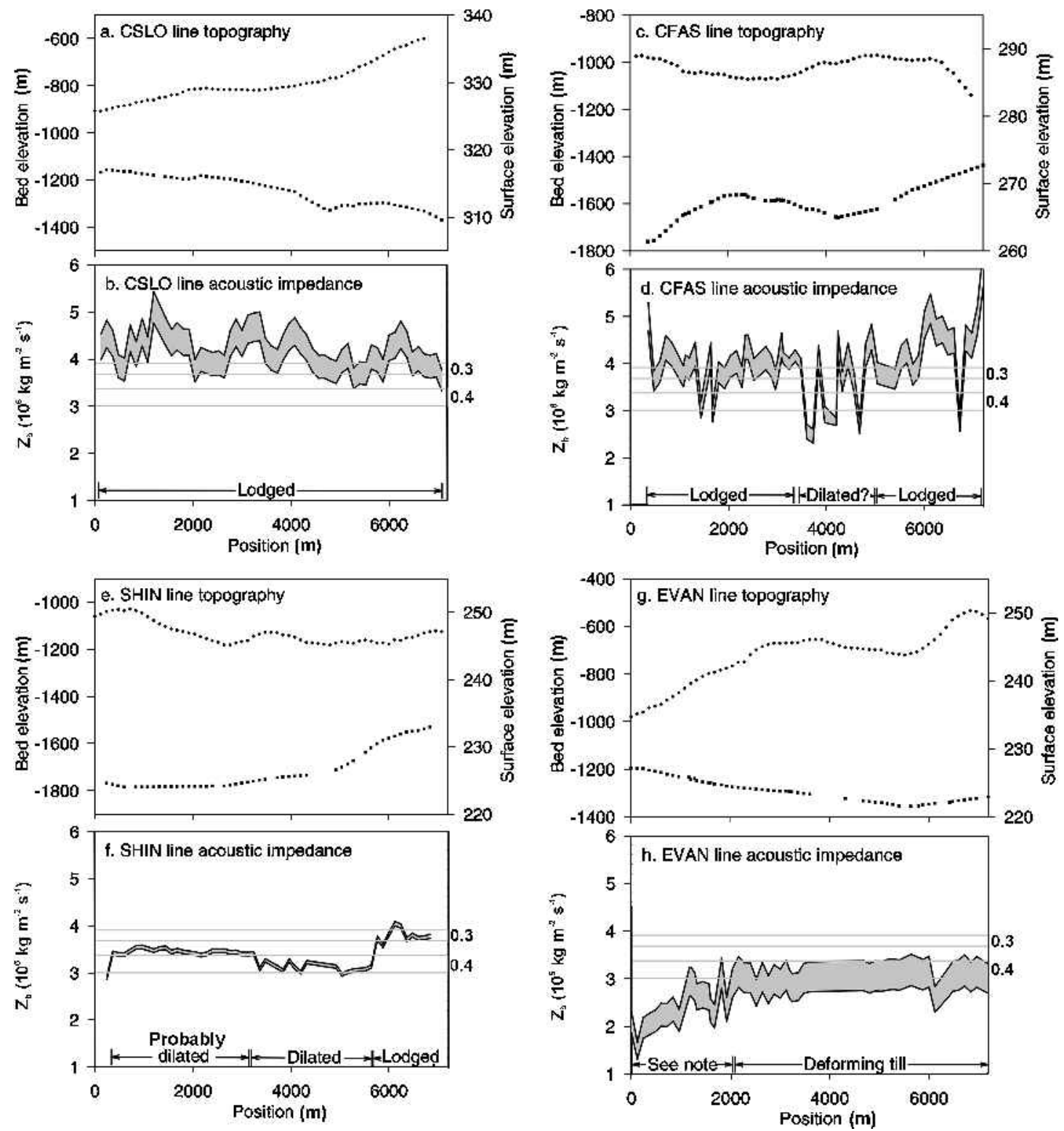

Fig. 4. Results of the four seismic profiles. a, c, e and $g$ show profiles of topography, including surface elevation (filled circles) from optical survey of shot locations and basal elevation calculated from surface elevation and seismic ice-thickness measurements. $b, d$, $f$ and $h$ show profiles of calculated acoustic impedance $\left(z_{\mathrm{b}}\right)$. The range of acoustic impedances compatible with the measurements is shown by the width of the shaded area. This range was determined from the variance of acoustic impedances calculated for each shot. Also shown are the likely limits for the acoustic impedance of sediment with porosity 0.3 (lodged) and porosity 0.4 (dilated) given by Atre and Bentley (1993); along with an interpretation of the likely distribution of lodged and dilated sediment on each profile, based on these values. Note: the apparently low derived acoustic impedance for the section, 0-2000 m, on EVAN line implies high porosity, perhaps approaching that of water $\left(1.4 \times 10^{6} \mathrm{~kg} \mathrm{~m}^{-2} \mathrm{~s}^{-1}\right)$.

tions yielded a mean velocity and uncertainty for the middle point on each seismic profile (Table 1).

\subsection{Strain rate}

At least three times, the positions of two stakes towards either end of the seismic profile were measured in relation to the central stake using the stop-go kinematic GPS technique. The relative displacement of these eccentric stakes allowed us to calculate the lateral strain rate along the seismic profile (Table 1). These data show that none of the ice streams has significant deformation on the central portion between their shear margins: they all move largely by plug flow.

\subsection{Surface gradient}

For three of our seismic profiles (CSLO, CFAS, SHIN) we completed $5 \mathrm{~km}$ kinematic GPS sorties, up and down the direction of flow from the central stake. The surface elevation data collected during these sorties were used to calculate the surface slope of the glacier (Table 1). On the EVAN line we used two digital elevation models of the area (Bamber and Bindschadler, 1997; Liu and others, 1999) to estimate the surface slope.

\subsection{Planimetric dimensions}

Other dimensions of the ice streams near the seismic profiles shown in Table 1 were derived directly from ERS-1 SAR images (Fig. 2) of the area. These included the width of the ice stream between the shear margins, and the width of the shear margins themselves, taken to be equal to the width of 


\begin{tabular}{|c|c|c|c|c|}
\hline & EVAN line & SHIN line & CFAS line & CSLO line \\
\hline Lat./long. of centre of line & $\begin{array}{c}76^{\circ} 04^{\prime} 31^{\prime \prime} \mathrm{S}, \\
76^{\circ} 45^{\prime} 33^{\prime \prime} \mathrm{W}\end{array}$ & $\begin{array}{c}78^{\circ} 17^{\prime} 06^{\prime \prime} \mathrm{S} \\
83^{\circ} 20^{\prime} 07^{\prime \prime} \mathrm{W}\end{array}$ & $\begin{array}{l}77^{\circ} 37^{\prime} 45^{\prime \prime} \mathrm{S}, \\
81^{\circ} 14^{\prime} 09^{\prime \prime} \mathrm{W}\end{array}$ & $\begin{array}{l}77^{\circ} 40^{\prime} 10^{\prime \prime} \mathrm{S}, \\
82^{\circ} 00^{\prime} 01^{\prime \prime} \mathrm{W}\end{array}$ \\
\hline Date of occupation & 15 Jan. 2000 & 11 Dec. 1999 & 2 Jan. 2000 & 20 Dec. 1999 \\
\hline Mean ice thickness (m) & 1584 & 2016 & 1920 & 1630 \\
\hline Downstream surface slope (\%) & 0.0029 & 0.005 & 0.0039 & 0.0068 \\
\hline Width between shear margins $(\mathrm{km})$ & $\sim 70$ & $\sim 20$ & $\sim 12$ & $\sim 17.5$ \\
\hline Width of shear margins $(\mathrm{km})$ & 2.5 & 3,5 & $1.5,2.5$ & $3,0.5$ \\
\hline Velocity of central stake $\left(\mathrm{m} \mathrm{a}^{-1}\right)$ & $464 \pm 30$ & $399 \pm 5$ & $180 \pm 19$ & $36 \pm 22$ \\
\hline $\begin{array}{l}\text { Velocity of eccentric stakes (true-left, true-right as } \% \text { of velocity at } \\
\text { central stake) }\end{array}$ & $94.1,100.0$ & $100.1,98.6$ & $99.6,95.7$ & $98.8,102.0$ \\
\hline Mean acoustic impedance across line $\left(10^{6} \mathrm{~kg} \mathrm{~m}^{-2} \mathrm{~s}^{-1}\right)$ & 2.77 & 3.41 & 3.97 & 4.13 \\
\hline Standard deviation of acoustic impedance across line $\left(10^{6} \mathrm{~kg} \mathrm{~m}^{-2} \mathrm{~s}^{-1}\right)$ & 0.39 & 0.26 & 0.65 & 0.33 \\
\hline Uncertainty in acoustic impedance $\left(10^{6} \mathrm{~kg} \mathrm{~m}^{-2} \mathrm{~s}^{-1}\right)$ & 0.58 & 0.03 & 0.38 & 0.52 \\
\hline Calculated driving stress $(\mathrm{kPa})$ & 40 & 53 & 66 & 97 \\
\hline Calculated basal restraint as $\%$ of driving stress & 97 & 91 & 83 & 99 \\
\hline Calculated mean basal shear stress across line $(\mathrm{kPa})$ & 39 & 49 & 55 & 97 \\
\hline
\end{tabular}

the bright margins in ERS-1 SAR images (Vaughan and others, 1994).

\subsection{Crevassing}

The seismic method we used to determine the subglacial acoustic impedance is valid only if the acoustic attenuation of the ice does not vary along the profile. Significant scattering by surface or subsurface crevasses would invalidate this assumption. To check for the presence of crevasses, we collected coincident profiles using a Pulse Ekko 100 GPR system capable of imaging the top few tens of metres of the ice sheet (Nath and Vaughan, in press). These data revealed crevasses only on the last $2 \mathrm{~km}$ of the EVAN line. As shown below, there does not appear to be any significant distortion of the acoustic impedance over this area.

\subsection{Calculation of basal shear stress}

Using the ancillary data shown in Table 1, we estimated the mean basal shear stress beneath the ice streams using a stress balance applied to the width of the glacier. We assume that the driving stress, $\sigma_{\mathrm{d}}$, as given by Paterson (1994) and calculated for the measured values at the centre of each profile, acts uniformly across the width between the shear margins, $2 A$. This is opposed by a mean basal stress, $T_{\mathrm{b}}$, and side-wall restraint transmitted through the true-left and true-right shear margins, $\sigma_{\text {mleft }}$ and $\sigma_{\text {mright, }}$ respectively. Thus

$$
2 A \rho g H \sin \alpha=2 A \tau_{\mathrm{b}}+H \sigma_{\text {mleft }}+H \sigma_{\text {mright }},
$$

where $H$ is the glacier thickness and $\rho$ is the density of ice.

We calculated $\sigma_{\text {mleft }}$, and $\sigma_{\text {mright }}$ using the measured velocity difference across the margin and the width of the margin to give the mean shear strain rate in the margin. From this strain rate and the power flow law, with temperature-dependent coefficient given by Paterson (1994, p. 8597), we calculated the shear stress transmitted across the shear margin. To account for likely softening of marginal ice, we applied an enhancement factor (cf. Jackson and Kamb, 1997). In line with earlier estimates, we chose enhancement factors of 1 for the margins of CSLO and 3 for the others which have higher strain rates. In fact, the calculated mean basal shear stresses are not particularly sensitive to the choice of enhancement factor, since in each case we found that the vast majority of the total resistance to the driving force results from the basal restraint (see Table 1).

\section{DISGUSSION OF DATA}

For each seismic profile, we derived the acoustic impedance, which is the product of compressional wave velocity and density. Several authors (Atre and Bentley, 1993; Smith, 1997 a, b) have argued that this material property can indicate the mechanical state of the subglacial material. Smith

Table 2. Comparison of the inferred conditions beneath each of the seismic profiles

\begin{tabular}{|c|c|c|c|c|}
\hline & EVAN line & SHIN line & CFAS line & CSLO line \\
\hline Subglacial material & $\begin{array}{l}\text { Dilated sediment across the } \\
\text { entire line }\end{array}$ & $\begin{array}{l}\text { Mostly dilated sediment, but } \\
\text { with probable patches of } \\
\text { lodged sediment }\end{array}$ & $\begin{array}{l}\text { Mostly lodged, but with a few } \\
\text { areas dilated }\end{array}$ & $\begin{array}{l}\text { Lodged material across the } \\
\text { entire line }\end{array}$ \\
\hline Dominant flow mechanism & $\begin{array}{c}\text { Deformation of subglacial } \\
\text { sediment }\end{array}$ & $\begin{array}{l}\text { Deformation of subglacial } \\
\text { sediment }\end{array}$ & $\begin{array}{l}\text { Mixed deformation of sublacial } \\
\text { sediment, and sliding }\end{array}$ & Deformation of ice \\
\hline
\end{tabular}


Table 3. Results from measurements of acoustic impedance on Rutford Ice Stream from surveys by Smith (1997a, b), with basal shear stress values calculated using the methodology given in section 4.6, and Whillans Ice Stream (formerly Ice Stream B; Blankenship and others, 1987) for which a near-zero basal shear stress has been estimated (Harrison and others, 1998; Whillans and others, 2001)

\begin{tabular}{|c|c|c|c|c|c|}
\hline Glacier & $\begin{array}{c}\text { Glacier velocity } \\
\qquad \mathrm{m} \mathrm{a}^{-1}\end{array}$ & Style of glacial flow & Interpreted subglacial conditions & $\begin{array}{l}\text { Acoustic impedance } \\
\qquad 10^{6} \mathrm{~kg} \mathrm{~m}^{-2} \mathrm{~s}^{-1}\end{array}$ & $\begin{array}{c}\text { Basal shear stress } \\
\mathrm{kPa}\end{array}$ \\
\hline New line, Rutford Ice Stream & 310 & Ice stream & Basal sliding & 3.88 & 78 \\
\hline Young line, Rutford Ice Stream & 368 & Ice stream & $\begin{array}{l}\text { Mixed deforming bed and glacial } \\
\text { sliding }\end{array}$ & 3.63 & 35 \\
\hline Tyree line, Rutford Ice Stream & 370 & Ice stream & $\begin{array}{l}\text { Mostly dilated sediment, but with } \\
\text { patches of basal sliding }\end{array}$ & 3.19 & 35 \\
\hline Upstream B camp, Whillans Ice Stream & 420 & Fast ice stream & Deforming bed & $2.8-3.4$ & $\sim 0$ \\
\hline
\end{tabular}

(1997a, b) proposed that the porosity of subglacial sediment could be estimated from acoustic impedance, and noted that the laboratory measurements reviewed by Atre and Bentley (1993) gave likely ranges of acoustic impedance 3.65-3.9 $\left(10^{6} \mathrm{~kg} \mathrm{~m}^{-2} \mathrm{~s}^{-1}\right)$ for lodged (non-deforming) sediment with porosity 0.3 , and $3.0-3.4\left(10^{6} \mathrm{~kg} \mathrm{~m}^{-2} \mathrm{~s}^{-1}\right)$ for dilated (deforming) sediment with porosity 0.4 . It is likely that acoustic impedance exceeding $5 \times 10^{6} \mathrm{~kg} \mathrm{~m}^{-2} \mathrm{~s}^{-1}$ would result from rock that is even partially lithified and that material below this figure is not likely to be lithified. Following Smith (1997b), we have used these values to interpret the likely state of the subglacial material beneath each of the profiles we have investigated. The results of this interpretation are shown in Figure 4 and summarized in Table 2.

We conclude that lodged sediment is probably ubiquitous beneath the CSLO line (Carlson Inlet) and underlies all but a few small areas beneath the CFAS line (Talutis Inlet). The SHIN line (Rutford Ice Stream) appears to be underlain by broad areas with three distinct bed types: one is lodged sediment, another is very likely dilated sediment, and the last has intermediate acoustic impedance, which probably indicates dilated sediment but appears to be dissimilar to the rest of the profile. The EVAN line (Evans Ice Stream) is entirely underlain by dilated sediment. This interpretation agrees with the gross pattern that we expect, the more rapidly flowing glaciers being underlain by increasing proportions of dilated sediment. For each ice stream, the interpretation is entirely in agreement with the previously assumed character and inferred flow mechanism of the ice stream, and we believe that this, in itself, confirms the seismic technique as an effective tool for determining the presence of dilated and lodged sediment beneath glaciers over a wide range of different flow conditions. However, closer examination of the data yields further conclusions.

\subsection{Mean acoustic impedance}

Both our measurements of the velocities of the eccentric stakes (see Table 1) and other studies that used SAR interferometry to map velocity variations on these glaciers (e.g. Rignot, 1998) indicate that these ice streams show little lateral deformation inside their shear margins. This implies that we may consider the central parts of the ice stream as responding to driving and restraining forces as approximately rigid bodies. This implies that there may be substantial local imbalances between driving stress and basal restraint: balance may only be achieved over length scales similar to the ice-stream width. We thus expect that the mean acoustic impedance along each line (as an indicator of the mean basal conditions) will correlate with the mean basal shear stress across the full width of the ice stream.

The mean acoustic impedance for each of the lines is given in Table 1, along with basal shear stress. Basal slipperiness, defined as the ratio of basal ice speed to basal shear stress, can be calculated from the data in Table 1, and similar data from the other seismic profiles on Rutford Ice Stream (Smith, 1997a) are given in Table 3. There is a moderate correlation between mean acoustic impedance and basal shear stress $\left(r^{2}=0.59\right)$, but there is much better correlation between mean acoustic impedance and basal slipperiness $\left(r^{2}=0.80\right.$; Fig. 5). For completeness, a measurement of acoustic impedance made at Upstream B on Whillans Ice Stream (formerly Ice Stream B) using a different seismic technique (Blankenship and others, 1987) is included in Table 3. This measurement is not, however, included in the regression since this measurement sampled only a small area of bed and does not represent a mean over the full width of the ice stream but rather a small portion of the bed. However, an additional problem remains in reconciling our data with those from Upstream B. Force-balance calculations at Upstream B suggest a much lower basal shear stress than on Evans Ice Stream, which we interpret to be entirely underlain by dilated sediments.

We take the quality of the correlation between basal slipperiness and mean acoustic impedance $\left(r^{2}=0.80\right)$ as confirmation that the basal drag beneath ice streams is highly dependent on the porosity of the material immediately below the ice and that this is a strong control on the ice-

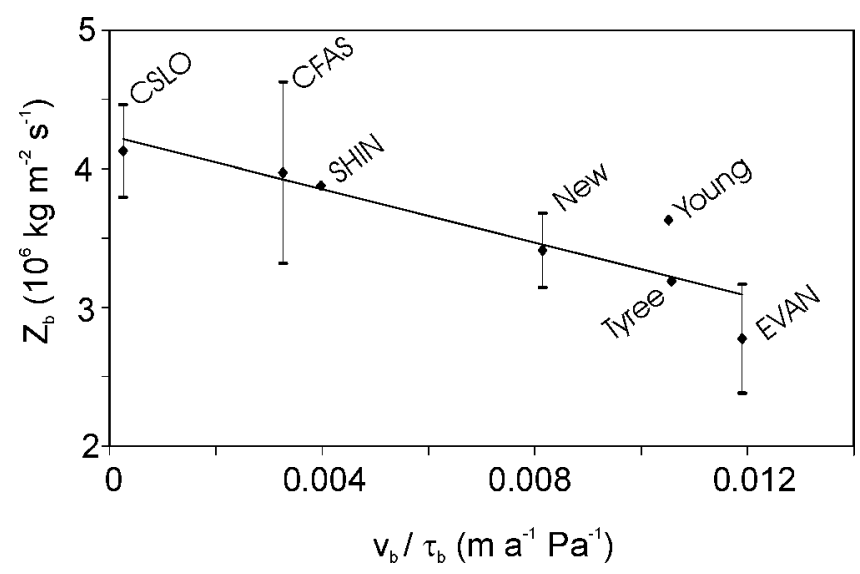

Fig. 5. Measured mean acoustic impedance vs calculated slipperiness (ratio of subglacial deformational velocity to basal shear stress). $R^{2}=0.80$. 
stream velocity. Furthermore, this indicates that, in addition to being a good diagnostic for the degree of porosity and hence dilatancy of the subglacial material, acoustic impedance can give a strong indication of the dynamic state of the material and potentially the maximum shear stress it can sustain.

\subsection{Variability in acoustic impedance}

Although the mean acoustic impedance for each line is the significant variable for comparison to the overall basal shear stress, the variability within each line is also of interest.

The two lines, CFAS and SHIN, which appear to show coexisting lodged and dilated sediment are particularly interesting (Fig. 4d and f). Both show abrupt jumps in acoustic impedance, from values that we take to be lodged sediment to those we take to be dilated sediment. With the possible exception of part of the SHIN line $(0-3 \mathrm{~km})$, which yields the lowest acoustic impedance that we would expect to be associated with dilated sediment, there are few areas in which the acoustic impedance appears at intermediate values.

Neither surface nor bed topography along these lines is well correlated with the distribution of dilated sediment, and nor is the distribution of dilated sediment correlated with the ice thickness. Similarly, we have found no particular correlation between the distribution of dilated sediment and the hydraulic potential calculated across the transverse profile using the formulae given by Flowers and Clarke (1999), although to investigate this thoroughly we would have to calculate hydraulic potential over an area rather than along a profile. This noted, for the present we find no particular evidence that subglacial water is being directed into areas of low hydraulic potential. This may imply that the distribution of lodged and dilated sediment is a function not simply of topography, but, perhaps of the material properties of the subglacial layer, or its deformation history. Furthermore, our profiles and those presented by Smith (1997a,b) show transitions from lodged to dilated sediment over a short horizontal distance, indicating that any intermediate state, if present, is not widespread.

Beneath Rutford Ice Stream (SHIN line), there appear to be generally wide zones $(\sim 2000 \mathrm{~m})$ in which distinct basal conditions occur. This suggests that there are large areas where the sediment is uniformly dilated, but also a substantial area where the sediment remains lodged. This interpretation has implications for the pattern and mechanism of water transport beneath Rutford Ice Stream. OnTalutis Inlet (CFAS line), however, there is considerably higher spatial variability that indicates narrow zones of dilated sediment beneath the ice stream, perhaps maintained by relatively localized areas of water.

\section{GONGLUSIONS}

We have applied a remote technique that allows spatially detailed mapping of material properties at the base of ice streams. These observations provide a comparative view of the basal conditions beneath Antarctic ice streams flowing at a variety of speeds by a variety of dominant flow mechanisms. We conclude that:

Each of the ice streams visited appears to be underlain by material with acoustic impedance typical of dilated to poorly lithified sediment, even though similar methods showed that glaciers in Svalbard (e.g. Smith and others, 2002) and slow-flowing ice in Antarctica (Smith, 2000) were underlain by material with much higher acoustic impedances.

The mean acoustic impedance across these ice streams correlates well with the calculated slipperiness of the bed, indicating that acoustic impedance is not only a good diagnostic for the porosity of the subglacial material, but also a strong indicator of its dynamic state.

Beneath two ice streams, lodged (non-deforming) and dilated (deforming) sediment coexist. The distribution of sediment types is not obviously controlled by basal topography or ice thickness, and our data do not indicate that the distribution is controlled by hydraulic potential. The factors controlling the distribution may thus be complex material properties or a function of the sediment deformation history. However, the transitions between sediment types do appear to occur over short horizontal distances, supporting the idea that the transition from lodged to dilated sediment is essentially a catastrophic transition.

The material that underlies the stagnant portions of Carlson Inlet has acoustic impedance indicating that it is lodged sediment. This is entirely consistent with the hypothesis that Carlson Inlet was once a fast-flowing ice stream, is now in a stagnant phase, and might be revived by slightly raised basal water content.

Beneath Rutford Ice Stream (SHIN line), the overall driving stress is balanced by lodged and dilated sediment distributed in broad bands across the ice stream, and, even though each is $>2000 \mathrm{~m}$ wide, this apparently causes at most only a couple of per cent change in iceflow speed at the surface.

To understand more fully how subglacial conditions control glacier flow, we must consider similar measurements over an even wider range of glacial conditions which include portions of the ice sheet frozen to its bed and outlet glaciers flowing over crystalline bedrock, and consider further how measurements of acoustic impedance can be used to distinguish between the various models of ice-stream flow.

\section{AGKNOWLEDGEMENTS}

We thank S. Hinde for his unflagging technical assistance in the field, and all the support personnel at Rothera Station who made the fieldwork possible.

\section{REFERENGES}

Alley, R. B., D. D. Blankenship, C. R. Bentley and S. T. Rooney. 1986. Deformation of till beneath Ice Stream B, West Antarctica. Nature, 322(6074), 57-59

Atre, S. R. and C. R. Bentley. 1993. Laterally varying basal conditions beneath Ice Streams B and C, West Antarctica. f. Glaciol., 39(133), 507-514.

Bamber, J. L. and R. A. Bindschadler. 1997. An improved elevation dataset for climate and ice-sheet modelling: validation with satellite imagery. Ann. Glaciol., 25, 439-444.

Bamber, J. L., D. G. Vaughan and I. Joughin. 2000. Widespread complex flow in the interior of the Antarctic ice sheet. Science, 287(5456), 1248-1250.

Blankenship, D. D., C. R. Bentley, S.T. Rooney and R. B. Alley. 1987. Till beneath Ice Stream B. 1. Properties derived from seismic travel times. f. Geophys. Res., 92(B9), 8903-8911.

Boulton, G. S. and A. S. Jones. 1979. Stability of temperate ice caps and ice sheets resting on beds of deformable sediment. F. Glaciol., 24(90), 29-43.

Clarke, T. S., C. Liu, N. E. Lord and C. R. Bentley. 2000. Evidence for a recently abandoned shear margin adjacent to Ice Stream B2, Antarctica, from ice-penetrating radar measurements. 7. Geophys. Res., 105(B6), 
$13,409-13,422$.

Cuffey, K. M., H. Conway, B. Hallet, A. M. Gades and C. F. Raymond. 1999. Interfacial water in polar glaciers and glacier sliding at $-17^{\circ} \mathrm{C}$. Geophys. Res. Lett., 26(6), 751-754.

Doake, C. S. M., I. W. D. Dalziel and R. D. Crabtree. 1983. Subglacial morphology between Ellsworth Mountains and Antarctic Peninsula: new data and tectonic significance. In Oliver, R. L., P. R. James and J. B. Jago, eds. Antarctic earth science. Cambridge, etc., Cambridge University Press. Australian Academy of Science, 270-273.

Doake, C. S. M. and 7 others. 2001. Rutford Ice Stream, Antarctica. In Alley, R. B. and R. A. Bindschadler, eds. The West Antartic ice sheet: behavior and environment. Washington, DC, American Geophysical Union, 221-235. (Antarctic Research Series 77.)

Flowers, G. E. and G. K. C. Clarke. 1999. Surface and bed topography of Trapridge Glacier, Yukon Territory, Canada: digital elevation models and derived hydraulic geometry. f. Glaciol., 45(149), 165-174.

Frolich, R. M. and C. S. M. Doake. 1998. Synthetic aperture radar interferometry over Rutford Ice Stream and Carlson Inlet, Antarctica. f. Glaciol., 44(146), 77-92.

Frolich, R. M., D. G. Vaughan and C. S. M. Doake. 1989. Flow of Rutford Ice Stream and comparison with Carlson Inlet, Antarctica. Ann. Glaciol., 12, 51-56.

Goldstein, R. M., H. Engelhardt, B. Kamb and R. M. Frolich. 1993. Satellite radar interferometry for monitoring ice sheet motion: application to an Antarctic ice stream. Science, 262(5139), 1525-1530.

Harrison, W. D., K. A. Echelmeyer and C. F. Larsen. 1998. Measurement of temperature in a margin of Ice Stream B, Antarctica: implications for margin migration and lateral drag. 7. Glaciol., 44(148), 615-624.

Hulbe, C. L. and A. J. Payne. 2001. The contribution of numerical modelling to our understanding of the West Antarctic ice sheet. In Alley, R. B. and R. A. Bindschadler, eds. The West Antartic ice sheet: behavior and environment. Washington, DC, American Geophysical Union, 201-219. (Antarctic Research Series 77.)

Jackson, M. and B. Kamb. 1997. The marginal shear stress of Ice Stream B, West Antarctica. F. Glaciol., 43(145), 415-426.

Liu, H., K. C. Jezek and B. Li. 1999. Development of an Antarctic digital elevation model by integrating cartographic and remotely sensed data: a geographic information system based approach. 7. Geophys. Res.,
104(B10), 23,199-23,213.

Nath, P. C. and D. G. Vaughan. In press. Sub-surface crevasse formation in glaciers and ice sheets. 7. Geophys. Res.

Paterson, W. S. B. 1994. The physics of glaciers. Third edition. Oxford, etc., Elsevier. Retzlaff, R. and C. R. Bentley. 1993. Timing of stagnation of Ice Stream C, West Antarctica, from short-pulse radar studies of buried surface crevasses. F. Glaciol., 39(133), 553-561.

Rignot, E. 1998. Radar interferometry detection of hinge-line migration on Rutford Ice Stream and Carlson Inlet, Antarctica. Ann. Glaciol., 27, 25-32.

Rose, K. E. 1979. Characteristics of ice flow in Marie Byrd Land, Antarctica. f. Glaciol., 24(90), 63-75.

Schmeltz, M., E. Rignot and D. R. MacAyeal. 2001. Ephemeral grounding as a signal of ice-shelf change. f. Glaciol., 47(156), 71-77.

Smith, A. M. 1997a. Basal conditions on Rutford Ice Stream, West Antarctica from seismic observations. F. Geophys. Res., 102(B1), 543-552.

Smith, A. M. 1997b. Variations in basal conditions on Rutford Ice Stream, West Antarctica. F. Glaciol., 43(144), 251-261.

Smith, A. M. 2000. Basal conditions on Rutford Ice Stream and Carlson Inlet: implications for ice stream flow. Filchner-Ronne Ice Shelf Programme Report 13, 72-77.

Smith, A. M., T. Murray, B. M. Davison, A. F. Glough, J. Woodward and H Jiskoot. 2002. Late-surge glacial conditions on Bakaninbreen, Svalbard, and implications for surge termination. 7. Geophys. Res., 107(B8), 2152. (10.1029/2001JB000475)

Vaughan, D. G. and J. L. Bamber. 1998. Identifying areas of low-profile ice sheet and outcrop damming in the Antarctic ice sheet by ERS-1 satellite altimetry. Ann. Glaciol., 27, 1-6.

Vaughan, D. G., R. M. Frolich and C. S. M. Doake.1994. ERS-1 SAR: stress indicator for Antarctic ice streams. In Space at the Service of our Environment. Proceedings of the Second ERS-1 Symposium, 11-14 October 1993, Hamburg, Germany. Vol. 1. Paris, European Space Agency, 183-186. (ESA SP-361.)

Vaughan, D. G., P. C. Nath and E. Le Meur. 2000. Science report of the Millennium Seismic Safari 1999/2000. Cambridge, British Antarctic Survey. (R/ 1999/S1.)

Whillans, I. M., C. R. Bentley and C. J. van der Veen. 2001. Ice Streams B and C. In Alley, R. B. and R. A. Bindschadler, eds. The West Antarctic ice sheet: behavior and environment. Washington, DC, American Geophysical Union, 257-281. (Antarctic Research Series 77.) 